\title{
Pattern of Smokeless Tobacco Use in Various Age Groups and Its Association with the Frequency of Micronuclei in Exfoliated Buccal Cells
}

\author{
Sonia Jaiswal', PK Sharma ${ }^{2}$ \\ ${ }^{1}$ Assisstant Professor, Department of Anatomy, Era's Lucknow Medical College, Lucknow, ${ }^{2}$ Professor and Head, Department of Anatomy, Era's Lucknow \\ Medical College, Lucknow.
}

\section{Abstract}

\begin{abstract}
Introduction: Exfoliated buccal epithelial cells serve as an ideal site for an assessment of genotoxic events. Exfoliative cytology is economical and minimally invasive, its specificity and sensitivity of over 95\% makes it an ideal diagnostic tool for mass screening purposes. An assessment of micronuclei in buccal epithelial cells gives a fair idea about the genotoxic events occurring in the oral cavity. Subjects and Methods: A case controlled study was performed on 300 participants. The participants were divided into four broad categories according to their pattern of consumption of smokeless tobacco. Thereafter they were subdivided in to various age groups. The distribution was done equally with 60 participants in each broad category. Results: The results in our study show that young adults consume the packaged form of smokeless tobacco while adults above 50 consumed tobacco leaves. Oral lesions were more common in young adults. Cellular alterations in the form of micronuclei were observed to have progressively increased from the control group to tobacco to gutkha users and the frequency of micronuclei was found to be highest in the oral lesions group. Conclusion: Certain lifestyle factors, such as consumption of smokeless tobacco are one of the major factors causing oral lesions. Frequency of micronuclei was assessed in exfoliated buccal epithelial cells. Maximum number of micronuclei was found in the oral lesion group. The age group with maximum cellular alterations was between 30-40 years. Hence we conclude that an assessment of micronuclei can be used as a biomarker for mass screening purposes since it is economical and a non- invasive procedure.
\end{abstract}

Keywords: Exfoliative Cytology, Micronuclei, Oral Lesions.

Corresponding Author: Dr. PK Sharma, Professor and Head, Department of Anatomy, Era's Lucknow Medical College, Lucknow.

Received: September 2019

Accepted: September 2019

\section{Introduction}

As age advances the physiological efficiency decreases leading to homeostatic imbalance thus making old age prone to illness. There are various studies that suggest increased genomic instability which is often associated with aging owing to decreased repair of damaged DNA ${ }^{[1,2]}$. There are reports which also suggest that peripheral lymphocytes ${ }^{[3,4]}$ and exfoliated epithelial cells are a good source to assess any kind of genomic damage. Apart from age related factors certain other factors such as various medical procedures, micronutrient deficiency, lifestyle factors may affect DNA metabolism or repair ${ }^{[5]}$ Chewing and smoking of tobacco along with consumption of alcohol are some of the common social habits in India ${ }^{[6]}$.Dry tobacco-areca nut preparations such as paan masala, gutkha and mawa are very popular amongst individuals and have a very high addictive potential. According to a survey, it has been estimated that there are 250 million smokeless tobacco users who are ten or more than ten years of age ${ }^{[7]}$. Tobacco consumption is one of the most important risk factors for oral cancer. Nearly $50 \%$ males and $25 \%$ females are affected by cancers related to tobacco ${ }^{[8]}$.Oral squamous cell carcinoma may develop de novo or may arise from various premalignant lesions. A timely intervention at appropriate levels may help in prevention and control of lesions associated with tobacco It is therefore essential to have reliable, relevant and minimally invasive biomarkers to improve the implementation of bio monitoring diagnostics for treatment of diseases caused by or associated with genetic damage. The micronuclei assay is an excellent method to serve as a biomarker which detects chromosomal loss or malfunction of mitotic spindles ${ }^{[9]}$.

\section{Subjects and Methods}

The case controlled study was conducted on 300 participants after an ethical committee clearance. A written informed consent was taken from each participant.

The participants were divided into four broad groups (each group had 60 participants), those who consume tobacco, those consuming gutkha, those subjects with lesions and the 
control group.

Participants were split into various age groups according to their consumption patterns

Upto 20years

20-30years

$30-40$ years

40-50years

50years and above

\section{Smear Preparation Using Exfoliative Cytology}

Before sampling, each individual was asked to rinse his/her mouth thoroughly with tap water. The exfoliated cells were obtained by scraping the buccal mucosa with a moistened wooden spatula, the scraped cells were placed on clean glass slides and smears were prepared. The smears were fixed with 95\% ethyl alcohol. All the cytologic smears were stained withPapanicolaou stain (fig 1) andhaematoxylene and eosin stain (fig 2). At least 2 smears per individual were prepared and100cellsper smear were examined for micronuclei under 40x and 100x magnification using Tolbert's criteria.

\section{Tolbert et al criteria}

States that for an assessment of micronuclei the cells must have;

1. Round smooth perimeter of a cell with an intact membrane

2. Diameter of the micronucleus must be less than one third the diameter of the associated nucleus, but large enough to discern shape and colour.

3. Staining intensity and hue should be similar to the nucleus.

4. Texture should be similar to nucleus.

5. Micronuclei should be in the same focal plane as nucleus.

6. Absence of overlap of cells or nuclei with a bridge to the nucleus.

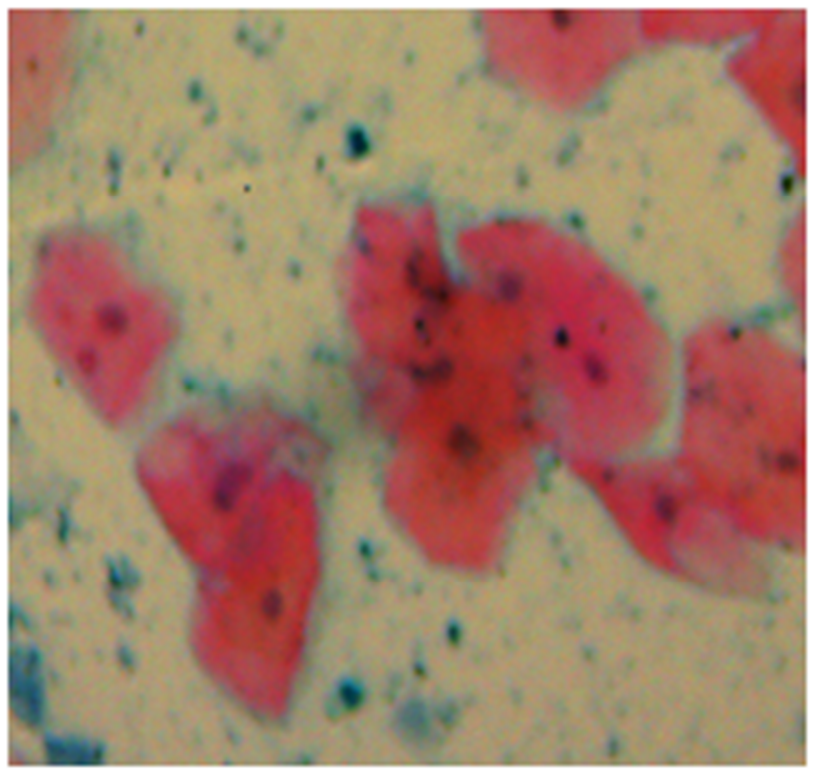

Figure 1: Shows a buccal smear stained with PAP, arrows indicate micronuclei as seen under a light microscope $(40 \mathrm{x}$ magnification)

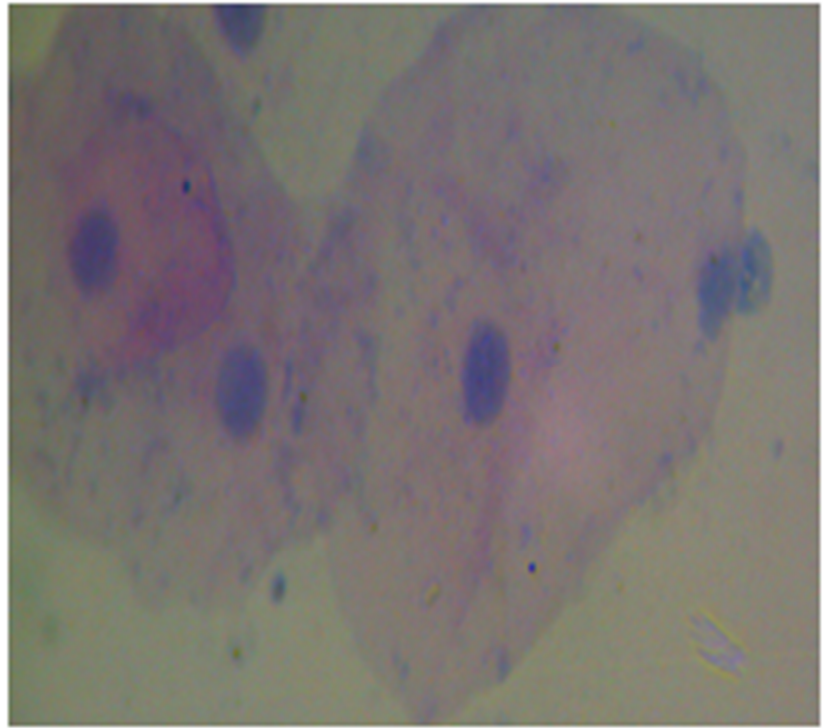

Figure 2: shows a buccal smear stained with haematoxylin and eosin as seen under a light microscope (40x magnification)

\section{Results}

After an evaluation of the participants according to a structured questionnaire and an interview we found that participants under 20years were habituated to gutkha (a preparation of areca nut with tobacco). We found that in the age group of 20-30 yrs youngsters were not only habituated to gutkha but were also diagnosed with oral lesions. Participants in the age group between 30-40 years not only used tobacco and gutkha but were diagnosed with oral lesions as well. We found that although the consumption pattern of participants in the age group of 40-50 years was same yet they were not diagnosed with any oral lesion.

\begin{tabular}{|c|c|c|c|c|c|c|c|}
\hline \multicolumn{8}{|c|}{ Table 1: } \\
\hline \multirow[t]{2}{*}{ Age } & \multirow[t]{2}{*}{ Group } & \multirow[t]{2}{*}{ Mean } & \multirow[t]{2}{*}{ SD } & \multirow[t]{2}{*}{ Min. } & \multirow[t]{2}{*}{$\begin{array}{l}\text { Max } \\
\text {. }\end{array}$} & \multicolumn{2}{|c|}{$\begin{array}{l}\text { Kruskal Wallis } \\
\text { Test }\end{array}$} \\
\hline & & & & & & chi sq & p-value \\
\hline \multirow{2}{*}{$\begin{array}{l}\text { Till } 20 \\
\text { yrs }\end{array}$} & Normal & 1.00 & .000 & 1 & 1 & \multirow[t]{2}{*}{7.596} & \multirow[t]{2}{*}{0.006} \\
\hline & Gutkha & 1.71 & .896 & 1 & 4 & & \\
\hline \multirow[t]{2}{*}{$\begin{array}{l}20-30 \\
\text { yrs }\end{array}$} & Gutkha & 2.13 & $\begin{array}{l}1.22 \\
9\end{array}$ & 1 & 6 & \multirow[t]{2}{*}{8.873} & \multirow[t]{2}{*}{$<0.001$} \\
\hline & Lesion & 2.42 & $\begin{array}{l}1.12 \\
9\end{array}$ & 1 & 6 & & \\
\hline \multirow{4}{*}{$\begin{array}{l}30-40 \\
\text { yrs }\end{array}$} & Normal & 1.00 & .000 & 1 & 1 & \multirow[t]{4}{*}{41.005} & \multirow[t]{4}{*}{$<0.001$} \\
\hline & Tobacco & 1.50 & .650 & 1 & 3 & & \\
\hline & Gutkha & 1.82 & $\begin{array}{l}1.14 \\
4 \\
\end{array}$ & 1 & 6 & & \\
\hline & Lesion & 2.54 & $\begin{array}{l}1.14 \\
5\end{array}$ & 1 & 5 & & \\
\hline \multirow{4}{*}{$\begin{array}{l}40-50 \\
\text { yrs }\end{array}$} & Normal & 1.03 & .183 & 1 & 2 & \multirow[t]{4}{*}{45.097} & \multirow[t]{4}{*}{$<0.001$} \\
\hline & Tobacco & 1.47 & .733 & 1 & 4 & & \\
\hline & Gutkha & 1.74 & .857 & 1 & 4 & & \\
\hline & Lesion & 2.13 & .963 & 1 & 5 & & \\
\hline \multirow{2}{*}{$\begin{array}{l}\text { above } 50 \\
\text { yrs }\end{array}$} & Tobacco & 1.49 & .843 & 1 & 6 & \multirow[t]{2}{*}{55.646} & \multirow[t]{2}{*}{$<0.001$} \\
\hline & Gutkha & 2.38 & $\begin{array}{l}1.17 \\
6\end{array}$ & 1 & 6 & & \\
\hline
\end{tabular}


In the age group below 20 years, the mean frequency/cell of Micronuclei formation was found to be more in the Gutkha group $(1.71 \pm 1.10)$ than the group of normal subjects $(1.00 \pm 0.00)$.

According to the Kruskal Wallis Testtest the difference in mean frequency/cell of Micronuclei formation among the two groups is found to be highly significant $(\mathrm{p}=0.006)$.

In the age group below 20 - 30 years, the mean frequency/cell of Micronuclei formation was found to be more in the Lesion group $(2.42 \pm 1.13)$ than the group of normal subjects $(2.13 \pm 1.23)$.

According to the Kruskal Wallis Testtest the difference in mean frequency/cell of Micronuclei formation among the two groups is found to be highly significant $(p<0.001)$.

In the age group $30-40$ years, the mean frequency/cell of Micronuclei formation was found to be highest in the lesion group $(2.54 \pm 1.15)$ followed by the group of Gutkha users

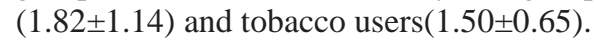

The mean frequency/cell of Micronuclei formation was minimum (1.00 \pm 0.00$)$ in the group of normal subjects.

According to the Kruskal Wallis Test the difference in mean frequency/cell of Micronuclei formation among various groups in the age group $30-40$ years is found to be highly significant $(\mathrm{p}<0.001)$.

In the age group $40-50$ years, the mean frequency/cell of Micronuclei formation was found to be highest in the lesion group $(2.13 \pm 0.96)$ followed by the group of Gutkha users (1.74 \pm 0.86$)$ and tobacco users $(1.47 \pm 0.73)$.

The mean frequency/cell of Micronuclei formation was minimum (1.03 \pm 0.18$)$ in the group of normal subjects.

According to the Kruskal Wallis Test the difference in mean frequency/cell of Micronuclei formation among various groups in the age group $40-50$ years is found to be highly significant $(\mathrm{p}<0.001)$. In the age group above 50 years, the mean frequency/cell of Micronuclei formation was found to be more in the Gutkha group $(2.38 \pm 1.18)$ than the group of tobacco users $(1.49 \pm 0.84)$. According to the Kruskal Wallis Testtest the difference in mean frequency/cell of Micronuclei formation among the two groups is found to be highly significant $(\mathrm{p}=0.006)$.

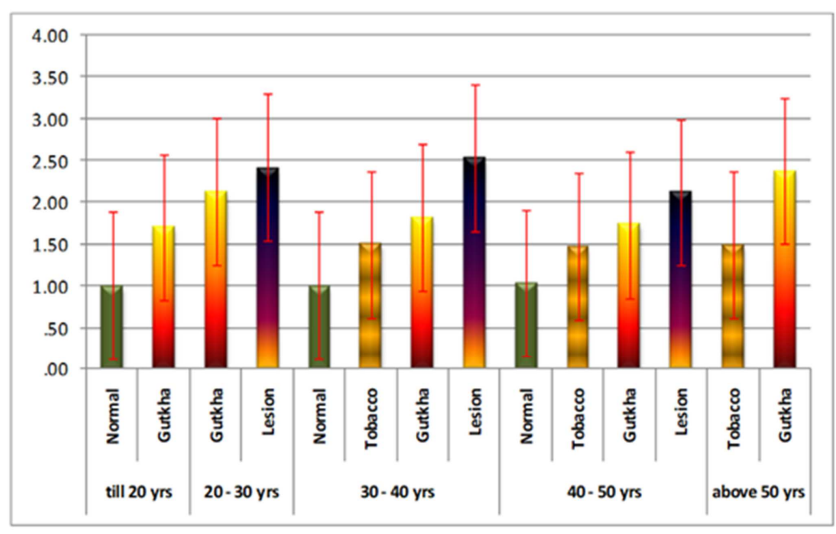

Graph 1: Age wise Inter-Group Comparison of Micronuclei Frequency/cell in Oral Mucosal Cells

\section{Discussion}

Smokeless tobacco use among young adults Stigler MH et al in 2006 found that smokeless tobacco is an emerging trend among young adults ${ }^{[10]}$.The younger children are more susceptible than the older ones. Packaged forms of tobacco products are more common in young adults. Arora $M$ et al in 2013 found that the easy availability, peer pressure and curiosity are the prime factors responsible for usage of tobacco products among teenagers ${ }^{[11]}$. In our study we found that young adults below the age of 20years consumed packaged tobacco products that aregutkha.

\section{Oral lesions}

Tobacco users consume commercially prepared packaged preparations. Tilakratne WM et al 2006 described Oral submucous fibrosis (OSMF) as a chronic disorder characterized by fibrosis of the lining mucosa of the upper digestive tract involving the oral cavity, oropharynx and frequently the upper third of the oesophagus ${ }^{[12]}$.Except in early forms of the disease, the clinical presentation is characteristic due to fibrosis of lamina propria and submucosa with an increasing loss of tissue mobility. OSMF is particularly associated with areca nut chewing, the main component of betel quid. In our study we found that oral submucous fibrosis was the commonest oral lesion that was prevalent among individuals below 50 years of age.

\section{Exfoliative cytology}

Several studies have shown good results with conventional oral brush cytology for the assessment of oral precancerous lesions. Cytopathologic evaluation of oral brush biopsies from leukoplakias and erythroplakias as a single method yields sensitivities for the detection of oral cancer, ranging from $92-100 \%$ and specificity between $92-94 \%$. Studies by Giunta J et al 1969, Sciubba JJ et al 1999, Svirsky JA et al 2002, Eisen D et al 2005 stated that exfoliative cytology is non-invasive, there is more chance of compliance with screening by this method in the general population ${ }^{[13-16]}$.We found that there was a compliance in sample collection since exfoliative cytology is minimally invasive.

\section{Measurement of micronuclei in oral exfoliated cells}

Autrup et al 1985, Vondracek et al 2001, Spivack S.D 2004 found that buccal cells form the first barrier in the oral cavity when anything is inhaled or ingested ${ }^{[17-19]}$. Buccal cells are capable of metabolizing carcinogens to reactive products. Tolbert et al 1992 found that the basal layer contains the stem cells that may express genetic damage (chromosome breakage or loss) as $\mathrm{MN}$ during nuclear division ${ }^{[20]}$.Casartelli et al in the year 2000 observed $\mathrm{MN}$ frequencies in exfoliated buccal cells in normal mucosa, precancerous lesions, and squamous cell carcinoma ${ }^{[21]}$. They concluded that the gradual increase in $\mathrm{MN}$ counts from normal mucosal to precancerous lesions to carcinoma suggested a link of this biomarker with neoplastic progression. We found a progressive increase in the number of micronuclei from the tobacco group to gutkha group to the group with oral lesions.

\section{Age and micronuclei}

As age advances the physiological efficiency decreases leading to homeostatic imbalances thus making old age prone to illness.

Certain studies indicated that oral squamous cell 


\section{Jaiswal d Sharma; Pattern of Smakeless Tabacca Use in Various Age Graups}

carcinomaaffected young people who were in the age group between $20-40$ years ${ }^{[22,23]}$.In our study most of the individuals affected by oral lesions were between 20-40 years.

A recent trend shows that at least $17 \%$ patients have malignancy in their 40 ' $\mathrm{s}^{[24]}$, however in our study we found that the age group between $30-40$ years of age was the high risk group

We did not find any individual above 50 years of age with oral lesion. An increased number of micronuclei in our study were found in exfoliated buccal cells of participants with oral lesions. In the elderly micronuclei are eliminated by apoptosis thus explaining a deficiency of micronuclei in this age group ${ }^{[25,26,27]}$.

\section{Conclusion}

Our study thus clearly explains the importance of early detection of cellular alterations for recognizing cases that need immediate or early intervention even if the there is an absence of changes of changes within the mucosa on oral inspection. An evaluation of precancerous and cancerous lesions with methods that assess the smears quantitatively will definitely improve the diagnostic potential of oral exfoliative cytology. Specific biomarkers such as micronuclei can help to establish preventive measures but will not predict whether a particular tissue may change to malignancy. No molecular biomonitoring can undermine the importance of medical health check-ups or histopathologicaldiagnosis, however it can be useful in screening high risk individuals who are exposed to lifestyle related factors inducing genotoxic events.

\section{References}

1. Garm C, Moreno-Villanueva M, Bürkle A, Petersen I, Bohr VA, Christensen K, et al. Age and gender effects on DNA strand break repair in peripheral blood mononuclear cells. Aging Cell 2013;12(1):58-66

2. Trzeciak AR, Barnes J, Ejiogu N, Foster K, Brant LJ, Zonderman $\mathrm{AB}$, et al. Age, sex, and race influence single-strand break repair capacity in a human population. Free RadicBiol Med 2008;45(12):1631-41.

3. Kazimírováa A, Barancokováa M, Dzupinkováa Z, Wsólová L, Dusinskáa M. Micronuclei and chromosomal aberrations, important markers of ageing: Possible association with XPC and XPD polymorphisms. Mutat Res 2009;661(1-2):35-40.

4. Joseph LJ, Patwardhan UN, Samuel AM. Frequency of micronuclei in peripheral blood lymphocytes from subjects occupationally exposed to low levels of ionizing radiation. Mutat Res 2004; 564(1):83-8.

5. Ogden GR, Cowpe JG, Wright AJ, Oral exfoliative cytology: review of methods of assessment, J Oral Pathol Med, 1997, 26(5):201-205

6. Stepanov I, Jensen J, Hatsukami D, Hecht SS. Tobacco specific nitrosmines in new tobacco products. Nicotine Tob Res 2006;8:309-13

7. Khandekar PS, Bagdey PS, and Tiwari RR, "oral cancer and Some epidemiological factors: a hospital based study," Indian Journal of Community Medicine,2006;31(3):157- 159 .
8. Fritzetal.,International Classification of Diseases For Oncology, World Health Organization, Geneva, Switzerland, 3rd edition, 2000

9. Ogden GR, Cowpe JG, Green NW. Detection of field change in 11. oral cancer using oral exfoliativecytologic study. Cancer. 1991; 68: 1611-5.

10. Stigler MH, Perry CL, Arora M, Reddy KS. Why are urban Indian 6th graders using more tobacco than 8th graders? Findings from Project MYTRI. Tob Control.2006;15:i54-i60.

11. Arora M, Nazar GP. Prohibiting Tobacco Advertising, Promotions And Sponsorships: Tobacco Control Best Buy. Indian Journal of Medical Research. 2013;137:6-9.

12. Tilakaratne WM, Klinikowski MF, Saku T, Peter TJ, Warnakulasuriya S. Oral submucous fibrosis: Review on aetiology and pathogenesis. Oral Oncol 2006;42:561-8

13. Giunta J, Meyer I, Shklar G. The accuracy of the oral biopsy in the diagnosis of cancer. Oral Surg Oral Med Oral Pathol 1969;28:5526.

14. Sciubba JJ. Improving detection of precancerous and cancerous oral lesions. Computer-assisted analysis of the oral brush biopsy. US Collaborative OralCDx Study Group. J Am Dent Assoc 1999;130:1445-57

15. Svirsky JA, Burns JC, Carpenter WM, Cohen DM, Bhattacharyya I, Fantasia JE, et al. Comparison of computer-assisted brush biopsy results with follow up scalpel biopsy and histology. Gen Dent 2002;50:500-3

16. Eisen D, Frist S. The relevance of the high positive predictive value of the oral brush biopsy. Oral Oncol 2005;41:753-5.

17. Autrup H, Seremet T, Arenholt D, Dragsted L, Jepsen A. Metabolism of benzo[a]pyrene by cultured rat and human buccal mucosa cells. Carcinogenesis 1985;6:1761-5

18. Vondracek M, Xi Z, Larsson P, Baker V, Mace K, Pfeifer A, et al. Cytochrome $\mathrm{P} 450$ expression and related metabolism in human buccal mucosa. Carcinogenesis 2001;22:481-8.

19. Spivack SD, Hurteau GJ, Jain R, Kumar SV, Aldous KM, Gierthy $\mathrm{JF}$, et al. Gene-environment interaction signatures by quantitative mRNA profiling in exfoliated buccal mucosal cells. Cancer Res 2004;64:6805-13.

20. Tolbert PE, Shy CM, Allen JW. Micronuclei and other nuclear anomalies in buccal smears: Methods development. Mutat Res 1992;271:69-77.

21. Casartelli G, Bonatti S, De Ferrari M, Scala M, Mereu P, Margarino G, Abbondandolo A. Micronucleus frequencie in exfoliated buccal cells in normal mucosa, precancerous lesions and squamous cell carcinonoma. Anal Quant CytolHistol. 2000; 22(6): 486- 92.

22. Dindgire SL, Gosavi S, Kumawat RM, Ganvir S, Hazarey V. Comparative Study of Exfoliated Oral Mucosal Cell Micronucleus Frequency in Potentially Malignant and Malignant Lesions. Int J Oral MaxillofacPathol 2012;3:15-20

23. Khammissa RA, Meer S, Lemmer J, Feller L. Oral squamous cell carcinoma in a South African sample: Race/ethnicity, age, gender, and degree of histopathological differentiation. J Can Res Ther 2014;10:908-14.

24. Rao SVK, Mejia G, Roberts-Thomson K, Logan R. Epidemiology of Oral Cancer in Asia in the Past Decade- An Update (20002012). Asian Pac J Cancer Prev 2013;14:5567-77.

25. Sharma P, Saxena S, Aggarwal P. Trends in the epidemiology of oral squamous cell carcinoma in western UP: An institutional study. Indian J Dent Res 2010;21:316-9.

26. Jaber MA, Porter SR, Speight P, Eveson JW, Scully C. Oral epithelial dysplasia: Clinical characteristics of western European residents. Oral Oncol 2003;39:589-96.

27. Chaudhary AR, Macwan R, Dudhia B, Patel P, Bhatia PV. Micronuclei: A biomarker for malignancy. Bhavnagar Univ J Dent 2013;3:1-7. 


\section{Jaiswal d Sharma; Pattern of Smakeless Salacca Use in Variaus Age Graups}

Copyright: (C) the author(s), publisher. Academia Anatomica International is an Official Publication of "Society for Health Care \& Research Development". It is an open-access article distributed under the terms of the Creative Commons Attribution Non-Commercial License, which permits unrestricted non-commercial use, distribution, and reproduction in any medium, provided the original work is properly cited.

How to cite this article: Jaiswal S, Sharma PK. Pattern of Smokeless Tobacco Use in Various Age Groups and Its Association with the Frequency of Micronuclei in Exfoliated Buccal Cells. Acad. Anat. Int. 2019;5(2):37-41.

DOI: dx.doi.org/10.21276/aanat.2019.5.2.11

Source of Support: Nil, Conflict of Interest: None declared. 